\title{
Tingkat Kesadahan Air Sumur di Dusun Gelaran 01 Desa Bejiharjo Karangmojo Gunungkidul, Yogyakarta
}

\author{
Evana $^{* a}$, Dhea Vella Nuralita Achmad ${ }^{a}$ \\ a Akademi Analis Kesehatan Manggala, Yogyakarta, 55198, Indonesia
}

INFO ARTIKEL

\begin{tabular}{l}
\hline Diterima 19 Oktober 2018 \\
Disetujui 30 Oktober 2018 \\
\hline Key word: \\
Hardness \\
Well water \\
Complexometry \\
\hline Kata kunci: \\
Kesadahan \\
Air sumur \\
Kompleksometri \\
\end{tabular}

\begin{abstract}
A B S T R A C T
Hard water is a term known for water with high content of Calcium (Ca) and Magnesium $(\mathrm{Mg})$ mineral. This type of water determines social-environment quality as well as people health in an area. Water with high degree of hardness could harm people health as it deteriorates people kidneys. The residence of Dusun Gelaran 01, Bejiharjo, Karangmojo, Gunungkidul use a 10-to-20 meter wells to obtain ground water for drinking and other household needs. The soil of Dusun Gelaran 01 is dominated by the red mediterranean association and black grumusol with limestone, so that the ground water has high amount of $\mathrm{Ca}$ and $\mathrm{Mg}$ minerals. Throughout the study, it can be determined the level of water hardness of 40 samples of Dusun Gelaran 01 well water by complexometry titration method. Out of all the samples tested $6(15 \%)$ samples were hard water, and $34(85 \%)$ samples were very hard water. The highest levels of total hardness was 490,2 $\mathrm{mg} / \mathrm{L}$. Total hardness levels have not exceeded the threshold according to Regulation of the Ministry of Health Republic of Indonesia No. 492/MENKES/PER/IV/2010.
\end{abstract}

\section{A B STRAK}

Air dengan konsentrasi mineral Kalsium (Ca) dan Magnesium (Mg) yang tinggi disebut dengan air sadah. Jenis air ini menentukan kualitas lingkungan sosial dan kesehatan masyarakat di suatu daerah. Air sangat penting untuk kehidupan manusia, akan tetapi air dengan tingkat kesadahan yang tinggi berbahaya untuk kesehatan karena dapat menyebabkan gangguan ginjal. Masyarakat Dusun Gelaran 01 yang berada di Desa Bejiharjo, Kecamatan Karangmojo, Kabupaten Gunungkidul menggunakan air tanah untuk minum dan kebutuhan rumah tangga lainnya. Air tanah di daerah ini diperoleh dengan cara membuat sumur, dengan kedalaman sumur berkisar antara 10-20 meter. Jenis tanah di daerah ini didominasi oleh asosiasi mediteran merah dan grumusol hitam dengan bahan induk batu kapur, sehingga air tanah di daerah tersebut mengandung mineral Ca dan Mg dalam jumlah yang cukup tinggi. Penelitian ini bertujuan untuk mengetahui tingkat kesadahan air dari 40 sampel air sumur yang digunakan masyarakat di Dusun Gelaran 01 dengan metode titrasi kompleksometri. Hasil penelitian menunjukkan dari 40 sampel yang diuji, 6 sampel (15\%) memiliki tingkat kesadahan tinggi dan 34 sampel (85\%) dengan tingkat kesadahan sangat tinggi. Kadar kesadahan total tertinggi yaitu sebesar 490,2 mg/L. Kadar kesadahan total masih dalam batas kadar maksimal sesuai dengan PERMENKES RI Nomor 492/MENKES/PER/IV/2010. *e-mail:

evana3009@gmail.com

*Telp:

$+6285729493309$ menimbulkan dampak yang besar terhadap kehidupan sosial dan ekonomi masyarakat.

Air yang baik adalah air yang memenuhi persyaratan fisika, kimia, mikrobiologi dan radioaktivitas [1]. Ketiga persyaratan tersebut merupakan satu kesatuan, sehingga jika ada 
satu parameter yang tidak memenuhi, maka air tersebut tidak layak digunakan. Salah satu parameter kimia dalam persyaratan kualitas air adalah jumlah kandungan unsur Kalsium (Ca) dan Magnesium (Mg) dalam air, yang keberadaannya disebut dengan kesadahan air [2].

Pada umumnya, tingkat kesadahan di berbagai tempat perairan berbeda-beda. Air tanah memiliki tingkat kesadahan yang lebih tinggi apabila dibandingkan dengan air permukaan, hal ini dikarenakan adanya kontak dengan batuan kapur yang ada pada lapisan tanah yang dilalui oleh air, sehingga memungkinkan unsur $\mathrm{Ca}$ dan $\mathrm{Mg}$ ikut terlarut [3].

Sebagian besar masyarakat masih memanfaatkan air tanah untuk memenuhi kebutuhan hidup sehari-hari, terutama untuk minum dan kebutuhan rumah tangga lainnya, salah satunya adalah masyarakat di Dusun Gelaran 01. Air tanah di daerah ini diperoleh dengan cara membuat sumur, dengan kedalaman berkisar antara 10-20 meter.

Dusun Gelaran 01 merupakan salah satu dusun yang terletak di Desa Bejiharjo, Kecamatan Karangmojo, Kabupaten Gunungkidul, Propinsi Daerah Istimewa Yogyakarta. Berdasarkan kondisi topografi, Dusun Gelaran 01 termasuk ke dalam zona tengah atau disebut wilayah pengembangan Ledok Wonosari yang terletak pada ketinggian $150-200 \mathrm{~m}$ di atas permukaan air laut [4].

Keberadaan air tanah di daerah penelitian pada umumnya dipengaruhi oleh porositas batuan dan rekahan-rekahan pada batuan, baik yang disebabkan oleh proses pelarutan ataupun tektonik, dengan kedalaman air tanah berkisar antara $60-120 \mathrm{~m}$ di bawah permukaan tanah [4]. Jenis tanah di daerah ini didominasi oleh asosiasi mediteran merah dan grumusol hitam dengan bahan induk batu kapur [4], sehingga air tanah di daerah tersebut diperkirakan memiliki sifat sadah karena mengandung Kalsium Bikarbonat $\left(\mathrm{Ca}\left(\mathrm{HCO}_{3}\right)_{2}\right)$ dan Magnesium Bikarbonat $\mathrm{Mg}\left(\mathrm{HCO}_{3}\right)_{2}$.

Gejala kesadahan air yang tinggi di daerah ini dapat diamati dari sabun yang sulit berbusa, sehingga masyarakat perlu menambahkan banyak sabun untuk keperluan mencuci. Air dengan tingkat kesadahan tinggi akan mengganggu daya kerja sabun, hal ini dikarenakan salah satu bagian sabun akan diikat oleh unsur $\mathrm{Ca}$ atau $\mathrm{Mg}$ membentuk endapan dan mencegah terjadinya busa dalam air [3].

Selain itu, masalah lain yang ditimbulkan oleh air dengan tingkat kesadahan yang tinggi adalah terdapat kerak di sekitar wadah pemanas air, mengakibatkan penghantaran panas menjadi berkurang, hal ini dikarenakan tersumbatnya katup-katup pada wadah pemanas sehingga membutuhkan waktu yang lama dalam proses pemanasan dan penggunaan bahan bakar yang berlebih [5].

Pada prinsipnya, unsur $\mathrm{Ca}$ dan $\mathrm{Mg}$ di dalam air dapat dihilangkan atau dikurangi kandungannya dengan beberapa proses, seperti pemanasan, pengendapan dan pertukaran ion tergantung dari jenis kesadahan (kesadahan sementara atau kesadahan tetap) yang terdapat di dalam air tersebut.

Kesadahan yang disebabkan oleh ion $\mathrm{Ca}^{2+}$ dan $\mathrm{Mg}^{2+}$ yang berikatan dengan ion Karbonat $\left(\mathrm{CO}_{3}{ }^{2-}\right)$ dan Bikarbonat $\left(\mathrm{HCO}_{3}^{-}\right)$, disebut kesadahan sementara, karena kesadahan dapat dihilangkan melalui proses pemanasan. Adanya proses pemanasan dapat menyebabkan senyawa-senyawa bikarbonat akan terurai menjadi Karbon dioksida $\left(\mathrm{CO}_{2}\right)$ dan air $\left(\mathrm{H}_{2} \mathrm{O}\right)$ sehingga air tersebut terbebas dari ion $\mathrm{Ca}^{2+}$ dan $\mathrm{Mg}^{2+}$, dan biasanya senyawa-senyawa bikarbonat tersebut akan mengendap pada dasar wadah pemanas air [6]. Sedangkan kesadahan yang disebabkan oleh ion $\mathrm{Ca}^{2+}$ dan $\mathrm{Mg}^{2+}$ yang berikatan dengan ion sulfat $\left(\mathrm{SO}_{4}{ }^{2-}\right)$ dan klorida $\left(\mathrm{Cl}^{-}\right)$, disebut kesadahan tetap karena tidak dapat dihilangkan dengan pemanasan, tetapi dengan cara proses pertukaran ion [3].

Kadar maksimum kesadahan yang diperbolehkan dalam air minum berdasarkan Peraturan Menteri Kesehatan Republik Indonesia Nomor 492/MENKES/PER/IV/2010 adalah $500 \mathrm{mg} /$ liter. Kesadahan dalam tingkat tertentu akan bermanfaat untuk kesehatan, namun jika kesadahan sudah melebihi batas maksimum yang diperbolehkan, maka dapat menyebabkan beberapa masalah kesehatan, diantaranya adalah urolithiasis (batu ginjal) dan cardiovascular disease (penyumbatan pembuluh darah jantung) [7]. Pemakaian dalam jangka 
waktu lama dapat menyebabkan gangguan ginjal akibat terakumulasinya endapan Kalsium Karbonat $\left(\mathrm{CaCO}_{3}\right)$ dan Magnesium Karbonat $\left(\mathrm{MgCO}_{3}\right)$ di dalam tubuh [8].

Berdasarkan dari permasalahan tentang efek air sadah bagi masyarakat, maka perlu dilakukan suatu penelitian untuk mengetahui tingkat kesadahan air sumur di Dusun Gelaran 01, Desa Bejiharjo, Karangmojo, Gunung Kidul, Daerah Istimewa Yogyakarta.

\section{Bahan dan Metode}

Empat puluh sampel air sumur diambil langsung dari Dusun Gelaran 01, Desa Bejiharjo, Kecamatan Karangmojo, Kabupaten Gunungkidul. Sumur-sumur tersebut merupakan sumur milik penduduk setempat yang masih aktif digunakan untuk memenuhi kebutuhan rumah tangga. Semua sampel air sumur dikumpulkan secara aseptik dalam wadah tertutup dan dibawa ke laboratorium untuk diperiksa kadar kesadahan total.

Metode yang digunakan dalam penetapan kadar kesadahan total yaitu titrasi kompleksometri mengacu pada [9], dengan cara cuplikan air sumur diambil sebanyak $25 \mathrm{~mL}$ secara triplo dan dimasukkan ke dalam labu erlenmeyer $250 \mathrm{~mL}$. Akuades ditambahkan sebanyak $25 \mathrm{~mL}$ dan dihomogenkan. Larutan buffer ammonia-ammonim klorida pH $10 \pm 0,1$ ditambahkan sebanyak $2 \mathrm{~mL}$, dan ditambahkan indikator Eriochrome Black T (EBT) sebanyak 30 $\mathrm{mg}$, diikuti dengan titrasi menggunakan larutan baku Dinatrium Etilen Diamin Tetra Asetat (EDTA) 0,01 M. EDTA merupakan larutan baku sekunder, sehingga untuk mengetahui nilai molaritasnya secara tepat dilakukan standarisasi menggunakan larutan baku primer $\mathrm{CaCO}_{3}[10]$.

Prinsip kompleksometri yaitu pembentukan ion-ion kompleks dalam larutan EDTA akan bereaksi dengan logam tertentu membentuk senyawa kompleks kelat yang larut. Pada $\mathrm{pH} 10 \pm 0,1$, ion-ion $\mathrm{Ca}^{2+}$ dan $\mathrm{Mg}^{2+}$ dalam contoh uji akan bereaksi dengan indikator EBT dan membentuk larutan berwarna merah keunguan. Jika EDTA ditambahkan sebagai titran, maka ion $\mathrm{Ca}^{2+}$ dan $\mathrm{Mg}^{2+}$ akan bereaksi dengan ligan EDTA membentuk senyawa kompleks yang stabil, molekul indikator terlepas kembali dan pada titik akhir titrasi larutan akan berubah warna dari merah keunguan menjadi biru [9]. Perhitungan kadar kesadahan total dilakukan menggunakan rumus sesuai persamaan (1) sebagai berikut [9] :

$$
\begin{aligned}
& \text { Kesadahan Total }\left(\mathrm{mg} \mathrm{CaCO}_{3} / \text { liter }\right) \\
= & \frac{1000}{V_{C . u}} \times V_{E D T A} \times M_{E D T A} \times 100
\end{aligned}
$$

dimana:

$\mathrm{V}_{\mathrm{c} . \mathrm{u}}=$ Volume larutan contoh uji (mL)

$\mathrm{V}$ EDTA $=$ Volume rata-rata larutan baku EDTA untuk titrasi $(\mathrm{mL})$

$\mathrm{M}_{\text {EDTA }}=$ Molaritas larutan baku EDTA untuk titrasi $(\mathrm{mmol} / \mathrm{mL})$

\section{Hasil dan Pembahasan}

Air sumur di Dusun Gelaran 01 mempunyai tingkat kesadahan yang berbedabeda. Berdasarkan klasifikasi seperti yang ditunjukkan pada Tabel 1, kesadahan air sumur di daerah penelitian termasuk dalam kategori tinggi hingga sangat tinggi.

Tabel 1. Klasifikasi Tingkat

\begin{tabular}{|c|c|}
\hline $\begin{array}{c}\text { Kadar } \\
\mathrm{CaCO}_{3} \\
\text { (mg/liter) }\end{array}$ & $\begin{array}{c}\text { Tingkat } \\
\text { Kesadahan }\end{array}$ \\
\hline $0-75$ & $\begin{array}{c}\text { Lunak } \\
\text { (soft) }\end{array}$ \\
\hline $75-150$ & $\begin{array}{c}\text { Sedang } \\
\text { (moderately hard) }\end{array}$ \\
\hline $150-300$ & Tinggi (hard) \\
\hline$>300$ & $\begin{array}{l}\text { Tinggi sekali } \\
\text { (very hard) }\end{array}$ \\
\hline
\end{tabular}
Kesadahan [3].

Hasil analisis kadar kesadahan $\mathrm{CaCO}_{3}$ (total) pada air sumur di Dusun Gelaran 01 dapat dilihat pada Tabel 2.

Berdasarkan hasil penelitian dari 40 sampel air sumur, terdapat 6 sampel (15\%) memiliki tingkat kesadahan yang tinggi dan 34 sampel (85\%) memiliki tingkat kesadahan yang sangat tinggi. Tingginya tingkat kesadahan disebabkan karena kondisi tanah di daerah penelitian mengandung batuan karbonat khususnya batu gamping karst [4]. Mineral utama penyusun batuan karbonat adalah kalsit $\left(\mathrm{CaCO}_{3}\right)$ dan dolomit $\left(\mathrm{CaMg}\left[\mathrm{CO}_{3}\right]_{2}\right)$ [11], 
sehingga air tanah di daerah ini mengandung ion $\mathrm{Ca}^{2+}$ dan $\mathrm{Mg}^{2+}$ dalam jumlah yang cukup besar.

Tabel 2. Nilai kesadahan $\mathrm{CaCO}_{3}$ (total) air sumur di Dusun Gelaran 01 Desa Bejiharjo.

\begin{tabular}{cccc}
\hline $\begin{array}{c}\text { Kode } \\
\text { Sampel }\end{array}$ & $\begin{array}{c}\text { Kadar } \\
\mathrm{CaCO}_{3} \\
\text { (mg/liter) }\end{array}$ & $\begin{array}{c}\text { Kode } \\
\text { Sampel }\end{array}$ & $\begin{array}{c}\text { Kadar } \\
\mathrm{CaCO}_{3} \\
\text { (mg/liter) }\end{array}$ \\
\hline A1 & 340,6 & B13 & 490,2 \\
\hline A2 & 474,7 & C1 & 387,0 \\
\hline A3 & 428,3 & C2 & 381,8 \\
\hline A4 & 428,3 & C3 & 335,4 \\
\hline A5 & 428,3 & C4 & 314,8 \\
\hline A6 & 443,8 & C5 & 314,8 \\
\hline A7 & 454,1 & C6 & 345,7 \\
\hline A8 & 397,3 & C7 & 356,0 \\
\hline B1 & 273,5 & C8 & 335,4 \\
\hline B2 & 361,2 & C9 & 319,9 \\
\hline B3 & 438,6 & C10 & 340,6 \\
\hline B4 & 418,0 & C11 & 330,2 \\
\hline B5 & 490,2 & C12 & 309,6 \\
\hline B6 & 433,4 & C13 & 278,6 \\
\hline B7 & 423,1 & C14 & 309,6 \\
\hline B8 & 438,6 & C15 & 278,6 \\
\hline B9 & 438,6 & C16 & 278,6 \\
\hline B10 & 474,7 & C17 & 242,5 \\
\hline B11 & 433,4 & C18 & 335,4 \\
\hline B12 & 448,9 & C19 & 294,1 \\
\hline
\end{tabular}

Keterangan: A = Sampel air sumur Rukun Tetangga (RT) 06, $\mathrm{B}=\mathrm{RT} 07 ; \mathrm{C}=\mathrm{RT} 08$.

Kesadahan di dalam air sangat dipengaruhi oleh adanya unsur $\mathrm{Ca}$ dan $\mathrm{Mg}$ yang bereaksi dengan $\mathrm{CO}_{2}$, yaitu gas yang mudah terlarut ke dalam perairan baik secara langsung karena terbawa air hujan, maupun melalui respirasi tumbuhan dan hewan akuatik dari hasil proses dekomposisi bahan organik [12]. Reaksi antara $\mathrm{H}_{2} \mathrm{O}$ dan $\mathrm{CO}_{2}$ akan membentuk asam karbonat $\left(\mathrm{H}_{2} \mathrm{CO}_{3}\right)$. Asam karbonat inilah yang akan bereaksi dengan $\mathrm{Ca}$ dan $\mathrm{Mg}$ ketika melewati perairan dengan dasar batuan gamping membentuk $\mathrm{Ca}\left(\mathrm{HCO}_{3}\right)_{2}$ dan $\left(\mathrm{Mg}\left(\mathrm{HCO}_{3}\right)_{2}\right)$, yang mengakibatkan perairan menjadi sangat sadah [12].

Nilai kesadahan total tertinggi yang terdapat di Dusun Gelaran 01 yaitu pada sampel B5 sebesar 490,2 mg/liter dan yang terendah pada sampel C17 sebesar 242,5 $\mathrm{mg} /$ liter. Hasil tersebut menunjukkan bahwa 100\% air sumur di Dusun Gelaran 01 masih berada di bawah standar baku maksimal kadar kesadahan total dalam air minum yang diperbolehkan sesuai Peraturan Menteri Kesehatan Republik Indonesia (<500 mg/liter).

Berdasarkan Angka Kecukupan Gizi (AKG) mineral (Ca dan Mg) dalam tubuh per hari, air minum yang dikonsumsi sebaiknya adalah air minum dengan tingkat kesadahan sedang (75 - 150 mg/liter). Kebutuhan Kalsium pada anak usia di bawah 10 tahun sebesar 1000 $\mathrm{mg} /$ hari dan pada orang dewasa sebesar 1200 mg/hari, sedangkan kebutuhan Magnesium pada anak usia dibawah 10 tahun sebesar 120 $\mathrm{mg} /$ hari dan pada orang dewasa sebesar 250 $\mathrm{mg} /$ hari [13].

Jika seseorang mengkonsumsi air dengan tingkat kesadahan sedang maka per harinya akan mendapat asupan sebesar 150 - $300 \mathrm{mg} \mathrm{Ca}$ dan $\mathrm{Mg}$ dengan asumsi air minum yang dikonsumsi per harinya minimal sebanyak 2 liter. Kadar tersebut sudah memenuhi kebutuhan unsur $\mathrm{Ca}$ dan $\mathrm{Mg}$ di dalam tubuh. Selain itu, setiap harinya manusia juga mendapat asupan $\mathrm{Ca}$ dan $\mathrm{Mg}$ dari sumber makanan dan minuman lainnya, seperti: susu, sayuran, kedelai, umbi-umbian, ikan, telur dan sebagainya sehingga jika mengkonsumsi air dengan kesadahan lebih dari $150 \mathrm{mg} /$ liter secara terus menerus dalam jangka waktu yang cukup lama, maka akan menyebabkan kelebihan kadar Ca dan $\mathrm{Mg}$ di dalam tubuh.

Departemen Kesehatan Republik Indonesia menetapkan standar persyaratan konsentrasi $\mathrm{Ca}$ di dalam air minum untuk menghindari efek yang tidak diinginkan dari terlalu rendah atau terlalu tingginya kadar $\mathrm{Ca}$ di dalam air minum yaitu 75 - $200 \mathrm{mg} / \mathrm{liter}$ sedangkan standar yang ditetapkan untuk $\mathrm{Mg}$ berkisar antara 30 - $150 \mathrm{mg} /$ liter [14].

Jika dilihat dari struktur tanah di Dusun Gelaran 01 yang didominasi mengandung batuan karbonat, maka kesadahan di daerah ini diperkirakan merupakan kesadahan sementara yang dapat dikurangi dengan proses pemanasan. Hal ini sesuai dengan Waluyo [15] yang menyatakan bahwa air yang bersifat sadah sementara banyak terdapat di daerah perbukitan kapur, antara Sragen bagian utara, Blora dan Gunungkidul, sedangkan air yang bersifat sadah tetap banyak terdapat di pantai antara lain Pekalongan, Bantul bagian selatan 
maupun daerah yang memiliki kandungan garam yang tinggi seperti sepanjang Bengawan Solo.

Hasil penelitian ini diharapkan dapat menjadi bahan pertimbangan bagi masyarakat khususnya di Dusun Gelaran 01, bahwa air yang mereka konsumsi memiliki tingkat kesadahan yang sangat tinggi, oleh karena itu disarankan kepada masyarakat yang akan memanfaatkan air sumur khususnya untuk kebutuhan minum, sebaiknya air tersebut dimasak dan disaring terlebih dahulu untuk mengurangi unsur $\mathrm{Ca}$ dan $\mathrm{Mg}$ di dalam air tersebut.

\section{Kesimpulan}

Berdasarkan hasil penelitian, kadar kesadahan $\mathrm{CaCO}_{3}$ (total) tertinggi dari 40 sampel air sumur di Dusun Gelaran 01 sebesar 490,2 mg/L. Kadar kesadahan total masih dalam batas kadar maksimal sesuai PERMENKES RI Nomor 492/MENKES/PER/IV/2010, dengan tingkat kesadahan tinggi sebesar $15 \%$ (6 sampel) dan tingkat kesadahan sangat tinggi sebesar 85\% (34 sampel).

\section{Daftar Pustaka}

1. Menteri Kesehatan Republik Indonesia. Peraturan Menteri Kesehatan Republik Indonesia No.492/MENKES/PER/IV/2010 Tentang Persyaratan Kualitas Air Minum, Kementerian Kesehatan Republik Indonesia: Jakarta, 2010.

2. Ramya, P.; Babu, A.J.; Reddy, E.T.; Rao, L.P. A Study On The Estimation Of Hardness In Ground Water Samples By Edta Tritrimetric Method. Int. J. Recent Sci. Res. 2015, 6, 4505-4507.

3. Marsidi, R. Zeolit Untuk Mengurangi Kesadahan Air. Jurnal Teknologi Lingkungan. 2001, 2, 1-10.

4. Kelompok Kerja Sanitasi Kabupaten Gunung Kidul. Buku Putih Sanitasi Kabupaten Gunung Kidul, BAPPEDA Gunungkidul: Wonosari, Indonesia, 2010.

5. Lethea, L. Impact of Water Hardness on Energy Consumption of Geyser Heating Elements. Water SA. 2017, 43(4), 614-625, DOI:10.4314/wsa.v43i4.09.

6. Sulistyani; Sunarto; Fillaeli, A. Uji Kesadahan Air Tanah di Daerah Sekitar
Pantai Kecamatan Rembang Propinsi Jawa Tengah. J. Sains Dasar. 2012, 1(1), 33-39.

7. Chawla, S.; Parashar, R.K. Environmentally Benign Method for Estimation of Hardness in Water. Int. J. Chem. Pharm. Rev. Res. 2015, 1(2), 49-54.

8. Sastrawijaya. Pencemaran Lingkungan. Rineka Cipta: Jakarta, Indonesia, 2002.

9. Badan Standarisasi Nasional. SNI 066989.12.2004 Air dan Air Limbah - Bagian 12: Cara Uji Kesadahan Total Kalsium (Ca) dan Magnesium $(\mathrm{Mg})$ dengan metode titrimetri. Badan Standarisasi Nasional: Jakarta, Indonesia, 2004.

10. Pursitasari, I. D. Kimia Dasar Analitik, Alfabeta: Bandung, Indonesia, 2014.

11. Tucker, M.E.; Wright, V.P. Carbonate Sedimentology, Blackwell Scientific Publication: Oxford, UK, 1990.

12. Effendi, H. Telaah Kualitas Air Bagi Pengelolaan Sumber Daya dan Lingkungan Perairan, Kanisius: Yogyakarta, Indonesia, 2003, ISBN 978-979-21-0613-8.

13. Menteri Kesehatan Republik Indonesia. Peraturan Menteri Kesehatan Republik Indonesia No.75 Tahun 2013 Tentang Angka Kecukupan Gizi Yang Dianjurkan Bagi Bangsa Indonesia, Kementerian Kesehatan Republik Indonesia: Jakarta, 2013.

14. Sutrisno, T. Teknologi Penyediaan Air Bersih, Rineka Cipta: Jakarta, Indonesia, 2006, ISBN 979-518-213-7.

15. Waluyo, L. Mikrobiologi Lingkungan, UMM Press: Malang, Indonesia, 2009. 